\title{
Analysis of Rice Profitability and Marketing Chain: A Case Study of District Sukkur Sindh Pakistan
}

\author{
Sanaullah Noonari", Ms. Irfana Noor Memon, Asif Ali Jatoi, Muola Bux peerzadio, \\ Abass Ali Chandio, Shoaib Ahmed Wagan, Asif Ahmed Sethar, Ghulam Yasin Kalwar, \\ Mukhtiar Ali Bhatti, Abdul Sami Korejo, Ghulam Mustafa Panhwar, Taimoor Shah
}

Department of Agricultural Economics, Faculty of Agricultural Social Sciences, Sindh Agriculture University, Tandojam, Pakistan

Email address:

sanaullahnoonari@gmail.com (S. Noonari)

\section{To cite this article:}

Sanaullah Noonari, Ms. Irfana Noor Memon, Asif Ali Jatoi, Muola Bux peerzadio, Abass Ali Chandio, Shoaib Ahmed Wagan, Asif Ahmed Sethar, Ghulam Yasin Kalwar, Mukhtiar Ali Bhatti, Abdul Sami Korejo, Ghulam Mustafa Panhwar, Taimoor Shah. Analysis of Rice Profitability and Marketing Chain: A Case Study of District Sukkur Sindh Pakistan. International Journal of Business and Economics Research. Vol. 4, No. 3, 2015, pp. 133-143. doi: 10.11648/j.ijber.20150403.16

\begin{abstract}
The purpose of this study was to investigate rice profitability and marketing in taluka Pano Akil district Sukkur Sindh. This study was based on primary data, which was collected from rice farming in study area. Analysis was done by using statistical technique like means, comparison of means and frequency distribution etc. Results shows rice farmer's on average per acre spent a total cost of production of Rs.41910.00, this included Rs.15200.00, Rs.2350.00, Rs.2900.00, Rs.7460.00, Rs.7400.00 and Rs.6600.00 on fixed cost, Land preparation, Seed and sowing, Farm inputs, Harvesting and threshing marketing costs respectively on capital inputs. Rice farmers on average per acre gross return of Rs.80200.00, Rs.70200.00 on rice grain and Rs.10000.00 on straw in taluka Pano Akil district Sukkur Sindh. The rice farmers on an average per acre earned during study, Rs.38290.00 on net income, Rs.80200.00 on gross income and Rs.41910.00 on total expenditure in taluka Pano Akil district Sukkur Sindh. Rice farmers on an average per acre gross income Rs.108400.00 and total expenditure is Rs.68310.00 in taluka Pano Akil district Sukkur Sindh area therefore they availed input output ratio of 1: 1.58 from rice growing in the study area. The selected rice farmers on a net income per acre earned Rs.38290.00and total expenditure Rs.41910.00 in taluka Pano Akil district Sukkur Sindh area therefore, they availed input output ratio of 1:0.91 from rice growing in the study area.
\end{abstract}

Keywords: Rice, Profitability, Marketing Costs, Net Returns, Cost-Benefit Ratio

\section{Introduction}

Rice is the staple food for more than half of the world's population. In Asia, more than $80 \%$ of the people live on rice, and their primary food security is entirely dependent on the volume of rice produced in this part of the world. However, rice production increases are now lagging behind population growth. Overall, the total global rice is declining gradually even with the extensive use of the modern varieties such as high yielding and hybrid varieties.

Rice (Oryza Sativa L.) is the seed of the monocot plants.Rice production in Pakistan holds an extremely important position in agriculture and the national economy. Pakistan is the world's fourth largest producer of rice, after China, India and Indonesia. Each year, it produces an average of 6 million tonnes and together with the rest of the South
Asia, the country is responsible for supplying 30\% of the world's paddy rice output. Most of these crops are grown in the fertile Sindh and Punjab region with millions of farmers relying on rice cultivation as their major source of employment. Rice is a high valued cash crop and is also a major export item. It accounts for 5.7 percent of the total value added in agriculture and 1.3 percent to GDP. Production of rice is provisionally estimated at 4991 thousand tons, which is 2.9 percent higher than last year. Rice was cultivated on an area of 2503 thousand hectares, showing an increase of 1.7 percent over last year. The higher production is due to favorable weather condition. Major producing areas include Larkana, Jacobabad, Shikarpur, Badin, Dadu \& Thatta districts of Sindh and .Gujranwala, Hafizabad, Sheikhupura, Sialkot, Jhang \& Okara of Punjab (GOP, 2012). 
Rice occupies 2.5 million hectare that is $10.9 \%$ of the total cultivated area with production of 5.1 million tonnes of milled rice. In Pakistan's agrarian economy rice plays multifarious roles. Firstly, it is second staple food and contributes more than 2 million tonnes to our national food requirement. Secondly, rice industry is an important source of employment and income for rural people. Thirdly, it contributes in the country's foreign exchange exchequer. For instance, about 2 million tonnes rice of worth 26 billion rupees was exported. The barter trade on Afghanistan border was in addition to this export. The significance of this commodity in our economy is evident from the above facts. Therefore, it is imperative to focus on the efforts needed to further improve its competitiveness in the international market. In Pakistan, rice is grown under diverse climatic and seraphic conditions. Basmati predominates in traditional rice. In Swat (zone 1) at high altitude mountain valleys, temperate Japonica rice's are grown. In the South of KPK, Sindh and Balochistan IRRI type long grain heat tolerant tropical rice is grown (FAO, 2007).

Rice is a cereal grain, it is the most widely consumed staple food for a large part of the world's human population, especially in Asia. It is the grain with the second-highest worldwide production, after corn, according to data for 2010. Since a large portion of maize crops are grown for purposes other than human consumption, rice is the most important grain with regard to human nutrition and caloric intake, providing more than one fifth of the calories consumed worldwide by humans. Genetic evidence has shown that rice originates from a single domestication 8,200-13,500 years ago in the Pearl River valley region of China. Previously, archaeological evidence had suggested that rice was domesticated in the Yangtze River valley region in China. From East Asia, rice spread to Southeast and South Asia. Rice was introduced to Europe through Western Asia, and to the Americas through European colonization. Today, the majority of all rice produced comes from China, India, Indonesia, Bangladesh, Vietnam, Thailand, Myanmar, Pakistan, Philippines, and Japan. Asian farmers still account for $92 \%$ of the world's total rice production. There are many varieties of rice and culinary preferences tend to vary regionally. In some areas such as the Far East or Spain, there is a preference for softer and stickier varieties. Rice is normally grown as an annual plant, although in tropical areas it can survive as a perennial and can produce a ration crop for up to 30 years. The rice plant can grow to $1-1.8 \mathrm{~m}(3.3-5.9 \mathrm{ft})$ tall, occasionally more depending on the variety and soil fertility. It has long, slender leaves $50-100 \mathrm{~cm}$ (20-39 in) long and $2-2.5 \mathrm{~cm}(0.79-0.98 \mathrm{in})$ broad. The small windpollinated flowers are produced in a branched arching to pendulous inflorescence $30-50 \mathrm{~cm}$ (12-20 in) long. The edible seed is a grain (caryopsis) $5-12 \mathrm{~mm}(0.20-0.47 \mathrm{in})$ long and 2-3 mm (0.079-0.118 in) thick (Humayun, 2012).

Rice is a major food staple and a mainstay for the rural population and their food security. It is mainly cultivated by small farmers in holdings of less than 1 hectare. Rice is also a wage commodity for workers in the cash crop or non- agricultural sectors. Rice is vital for the nutrition of much of the population in Asia, as well as in Latin America and the Caribbean and in Africa; it is central to the food security of over half the world population. Developing countries account for $95 \%$ of the total production, with China and India alone responsible for nearly half of the world output. World production of rice has risen steadily from about 200 million tonnes of paddy rice in 1960 to over 678 million tonnes in 2009. The three largest producers of rice in 2009 were China (197 million tonnes), India (131 Mt), and Indonesia (64 Mt). Among the six largest rice producers, the most productive farms for rice, in 2009, were in China producing 6.59 tonnes per hectare. At 44 million hectares, India had the largest farm area under rice production in 2009. The rice farm productivity in India were about $45 \%$ of the rice farm productivity in China, and about $60 \%$ of the rice farm productivity in Indonesia. The average world yield for rice was 4.3 tonnes per hectare, in 2010. Australian rice farms were the most productive in 2010 , with a nationwide average of 10.8 tonnes per hectare (FAOSTAT, 2012).

Rice is an important food crop and a major export item of Pakistan. It has been a major source of foreign exchange in recent years. Pakistan grows a high quality rice to fulfill domestic demand and also for exports. Rice account 4.9 percent of the value added in the agriculture and 1.0 percent of GDP. The area under rice crop in Pakistan during 2011-12 was 2571 hectares with total production of 6160 thousand Tons; whereas the total area of rice crop in Sindh was 361.2 hectares with total production 1230.3 Tones. Pakistan is an Agricultural country due to high increase in population it face major challenges of food scarcity, so for the completion of food needs of the peoples, need to grow high yielding varieties (GOP, 2012).

Rice is an important cereal food grain crop of the world with an excellent source of calories, in the form of starch, and has added benefits of providing protein with higher nutritional quality than other cereals grains. Different rice research institute i.e. IRRI, WARDA and USDA have a lot of germ plasma collections of rice for the improvement of rice varieties with respect to yield and yield contributing traits. Crop improvement program also depends on the utilization of germ spasm stock that is available in different rice research institutes of the world. Improving and increasing the world's supply will also depend upon the development and improvement of rice varieties with better yield potential, and to adopt various conventional and biotechnological approaches for the development of high yielding varieties that having resistance against biotic and a biotic stresses (Khush, 2005).

Thousands cultivars of rice have been evolved through selection which were cultivated in many centuries ago these were well adapted to the local environments. Many of those rice cultivars having good quality characteristics and higher yield potential under biotic and a biotic stress environments. Since the beginning of civilization, hundreds of locally adapted genotypes of aromatic rice's have evolved by human and through natural selection (Singh et al. 2000). 
In Pakistan's economy Rice is second food source after wheat and is an important foreign exchange earning commodity fetching about $\$ 950$ million annually. It is one of the highest water requiring crops, depending on early and late maturing varieties. Coarse grain varieties are early maturing while fine grain varieties are late maturing. Sixty two percent of total rice area is under fine varieties, 27 percent under course grain varieties, and 11 percent under of others varieties. Moreover, about 96 percent of fine varieties are grown in Punjab because there is suitable climate for maintaining the quality and aroma of these varieties. The yield of fine varieties is much lower than the course grain varieties but demand of fine rice is high in national and international markets. Most of the farmers prefer to grow fine varieties despite low yield high production cost and more water requirement (Khushk et al. 2011).

Improvement of the rice grain yield is the only possible and potential strategy to attain increased rice produce because of the reduction in rice cultivating area (Cassman, 1999).Hence, rice varieties with higher yield potential must be designed to enhance the total rice production of the world. Grain yield in rice is a quantitative/polygenic character and highly influenced by environment. Different rice varieties and germ plasma lines were selected on the basis of yield and yield contributing traits. Association of yield with corresponding yield components should be considered in determines the selection criteria of germ plasma on the basis of the variation (Habib et al. 2005).

The success of breeding program also depends upon the amount of genetic variability present in the population and extent to which the desirable traits are heritable. Different morph physiological traits play a very important role for more rice production with new plant type characteristics associated with plant yield (Yang et al. 2008). Phonological properties of rice are also associated with the yield potential of the different rice varieties for the selection of the best varieties that further involved in rice breeding program (Shahidullah et al. 2009).

\section{Objectives}

1. To describe socio-economic characteristics of the rice farmers in the study area.

2. To analyze the structure of rice productions costs and determine profitability of rice production in the study area.

3. To identify major constraints and opportunities in rice production and supply to market.

4. To suggest policy recommendations for rice policy on the basis of estimated rice yield response function.

\section{Materials and Methods}

The present study was conducted carried out with Rice varieties in Sindh province. This study was conducted through primary data collection from rice growers who had planted rice in taluka Pano Akil district Sukkur Sindh.
Primary data were collected using a well structured pre-tested questionnaire. The information was collected on farm size, varietal composition, labour costs, inputs costs, transportation and net returns of major rice varieties produced by the growers. The selection of rice grower was based on the criterion that they had planted seed on their field.

The study was restricted generally to gather primary data from taluka Pano Akil district Sukkur Sindh. It was selected as the universe of the study because it represents study rice production activities. The district is gifted naturally with fertile soil. The sample was supposed to contain rice farmers. A sample size of 60 respondents was selected through random sampling. As described above, the data was collected from taluka Pano Akil district Sukkur Sindh, Villages and respondents from this area were randomly selected.

Interview schedule was based on a well designed questionnaire. Comprehensive information was obtained face to face from the farmers involved in rice farming by the interviewer. Questionnaire was prepared in English language while the interview with respondents was done in local language i.e. Sindhi. Different features were covered in the questionnaire. Collected data was analyzed using the Statistical Package for Social Sciences (SPSS). Results obtained will be used for discussion and recommendations.

\subsection{Analytical Approaches}

Partial budgeting analysis techniques were used in analyzing the data collected from the samples of rice producers in taluka Pano Akil district Sukkur Sindh such analytical approaches produce simple results, which can be apprehended even by common farmers and interested persons. Different criteria were used to derive desirable results, which basically involve analysis of production process of rice, estimation of production costs, valuation of productivity or output and inferential analysis.

\subsection{Estimation of Production Cost}

Analysis of production cost expresses the way in which output is produced by input and the way to cooperate with each other in varying proportions to produce any given output such an analysis refers to "the relationship between the inputs of factors services and the output of product". Production cost refers to the out lay of funds for productive services; cost of any production period includes the value of input services transformed into the product. It is the value of the services of factors of production actually employed to produce a specific commodity. Thus, output is a function of the factor inputs. The various farm resources as they entered into the production process of rice crop in taluka Pano Akil district Sukkur Sindh was investigated and evaluated to estimate the production cost. The resource items allocated to rice production was very large and hence they were aggregated and classified to make the analysis manageable and useful.

\subsection{Resource Classification}

Economists generally classify resources employed to 
production function into four categories; they are termed as land, labour, capital and management. As a matter of fact, management is also a labour resource. In view of this, the resources allocated to rice production were aggregated into land, labour and capital. Thus production function developed to analyze the data collected from selected samples was $y=F$ $\left(\mathrm{x}_{1}, \mathrm{x}_{2}, \mathrm{x}_{3} \ldots \mathrm{x}_{\mathrm{n}}\right)$.In this equation $\mathrm{y} 1$ refer to the single commodity which may be produced, $\mathrm{x}_{1}, \mathrm{x}_{2}, \mathrm{x}_{3} \ldots \mathrm{x}_{\mathrm{n}}$ refers to land, labour and capital inputs etc., while ' $\mathrm{f}$ ' denotes the production function.

\subsection{Estimation of Land Inputs}

The land on sample farms was not perfectly homogenous. It varies in its inherent characteristics of productivity. Therefore land inputs were aggregated on the basis of unit (are/ hectare) sown under rice crop at the selected farms. Climate offer equal opportunity to all farmers in the area and hence it many have very insignificant effect on the comparison of efficiency of land resources. Therefore actual area sown under rice crop was taken into consideration to determine the land resource use. The estimating land inputs for rice crop on the sample farms, the following formula was used:

$$
\operatorname{Lip}=(\text { As } \times \text { cr })+(\text { As x Rli }) / \text { AS }
$$

Where

Lip = land input per unit of rice.

$\mathrm{As}=$ Area sown under rice

$\mathrm{Cr}=$ contract rent per unit

Rli $=$ Rate of land tax and irrigation charges

\subsection{Estimation of Labour Cost}

To compute labour costs used in the production of rice, labour engaged, number of days worked, wage rate paid per man per day / pair of bullocks employed along with working man and wage rate paid were investigated for each cultural operation carried out on the sample farms. The number of labour or pair of bullocks was multiplied with the respective working days to calculate man-work-days and bullock workdays per operation, then extent of labour inputs for various cultural operations involved in rice production were estimated by applying the formula.

$$
\mathrm{Lip}=(\mathrm{Mn} \times \mathrm{Hc})+(\mathrm{Mwd} \times \mathrm{Wr}) / \mathrm{As}
$$

Where

Lip=Labour input per unit of rice

$\mathrm{Mn}=$ Machine work hour

$\mathrm{Hc}=$ Hiring charges

Mwd=Man work days

$\mathrm{Wr}=$ Wage rate

Bwd= Bullock work day

$\mathrm{AS}=$ Are sown under rice crop

\subsection{Measurement of Capital Inputs}

Capital as a factor of production posses as distinct characteristics. It is many perishable, movable and strategic role in boosting up of productivity. Components of capital mostly used in the production of principal agricultural commodities were seed, fertilizer and farmyard manure, insecticides and pesticides, use of tractor power, implements and other machinery and tube wells. The application of these costs varies actual expenditure as incurred by farm entrepreneurs on obtaining the services of these capital inputs were investigated from individual samples and average were derived for all the sample farms.

To compute the cost of production incurred by farmers on capital inputs and the items such as seed, fertilizer, insecticides and pesticides etc. The quantities of these inputs used by farmers of rice cultivation and the prices at which the inputs were purchased or acquired were investigated. The following formula was evolved to compute per unit cost on these inputs.

$$
\mathrm{Cpu}=(\mathrm{Qs} \times \mathrm{Pr})+(\mathrm{Qf}+\mathrm{Pr})+(\mathrm{Qi} \times \mathrm{Pr}) / \mathrm{As}
$$

Where

$\mathrm{Cpu}=$ Capital inputs per unit of rice

Qs=Quantity of seed used

$\mathrm{Pr}=$ Price per unit of inputs

$\mathrm{Qf}=$ Quantity of fertilizer

Qi=Quantity of insecticides/pesticides

As $=$ Area sown

\subsection{Estimation of Marketing Cost}

The rice producers in taluka Pano Akil district Sukkur Sindh incurred marketing costs on the disposal of the produce. Such costs were estimated for the quantity of produce they sold in the market by using the following formula:

$$
\mathrm{Mc}=\mathrm{Qm}(\mathrm{Rl}+\mathrm{Rul}+\mathrm{Tr}) / \mathrm{As}
$$

Where

$\mathrm{Mc}=$ Marketing cost

Qm=Quantity of produce marketed

$\mathrm{Rl}=$ Rate of loading

$\mathrm{Rul}=$ Rate of unloading of rice

$\mathrm{Tr}=$ Transportation rate

The farmer also paid commission charges to the commission agents for intermediary services extended in the disposal of produce at 8 percent of sale of produce. Thus the commission charges were estimated after investigating the revenue received.

\subsection{Estimation of Returns}

While the produce retained by farmers for their home consumption was valued at prices prevailing in the area. The quantity of rice marketed by the farmers was timed with prices they received at the time of disposal by using following formula:

$$
\mathrm{VP}=(\mathrm{Q} \text { si } \mathrm{x} \operatorname{Pr})+\mathrm{Qs} \times \mathrm{Pr})+\operatorname{Pr}) / \mathrm{As}
$$


$\mathrm{Vp}=$ Value of product

Qs=Quantity sold

Pr=Price per unit

As $=$ Area sown

\subsection{Opportunity Cost Principle}

The entrepreneur from their own resources for which they incur no cash expenses incurs certain variable costs. They are referred to as implicit costs, and they are not clearly and plainly expressed in monetary terms. Such costs, in the present study, were calculated on the basis of opportunity cost principle.

This concept not only applies to those resources for which no price is available but also to purchase the input, if values are suspicious. Therefore, all implicit costs involved in rice production at the sample farms such as the rent of land, wage for family labour, use of own farm machinery or pair of bullock and implements were calculated at prices prevailing in the area during the period on the base of opportunity cost principle.

\section{Results}

Production is a process whereby some goods and services called inputs are transformed into other goods and services called outputs. Production of agriculture commodities not only results through the transformation of various inputs into outputs but it is also subject to the physical, natural and socio economic condition of the area. It is therefore necessary to have a brief account of the socio-economic indicators like family size, educational level etc. as prevailing in the study area, and to account the production practices as well as returns in physical and revenue terms. The present study was carried out to investigate the analysis of rice profitability and marketing in study area.

\subsection{Age}

Age is very important demographic factor which influences. The efficient allocation of resources it shows the ability to do work efficiency willingness to make progress and attitude towards various social and economic aspects of life age can be defined as total number of completed years since birth of a person.

Table 1. Age group of the rice farmers in the study area

\begin{tabular}{lll}
\hline Age & No. of respondents & Percentage \\
\hline 21-30 years & 16 & 26.66 \\
31-40 years & 12 & 20.00 \\
41-50 years & 20 & 33.33 \\
More than 50 years & 12 & 20.00 \\
Total & 60 & 100.00 \\
\hline
\end{tabular}

Table-1 this table shows the association of the age of the respond with the percent of rice farmer s age group of 21-30 years $26.66 \%, 31-40$ years $20.00 \%$ and $41-50$ years, $33.33 \%$ of rice t grower's age group. With more 50 years old farmers the percentage of rice growers age group $20.00 \%$ in the study area.

\subsection{Education}

Education and training make the grower skilled and more efficient, education not only enhance the standard of living but also help in maintenance of farms which can bring prosperity of his family. Therefore, literacy level was asked from the selected rice growers in the study area.

Table 2. Education of the rice farmers in the study area

\begin{tabular}{lll}
\hline Education level & No. of respondents & Percentage \\
\hline Illiterate & 15 & 25.00 \\
Primary & 21 & 35.00 \\
Middle & 11 & 18.30 \\
Matriculate & 8 & 13.30 \\
Intermediate & 4 & 6.70 \\
Graduate & 1 & 1.70 \\
Total & 60 & 100.00 \\
\hline
\end{tabular}

Table-2 that the education level of selected growers was in order of $35.00 \%$ primary (5-years), $18.30 \%$ middle (8-years), $13.30 \%$ matriculate (10years) $6.70 \%$ intermediated (12-years), $1.70 \%$ graduate beyond the $25.00 \%$ of rice respondents were illiterate in the study area.

\subsection{Farming Experience}

Farming is growing crops or keeping animals by people for food and raw Materials farming are a part of agriculture. Experience comprises knowledge of or skill of something or some event gained through involvement in or exposure to that thing or Event. The history of the word experience aligns it closely with the concept of experiment.

Table 3. Farming Experiment of the rice farmers in the study area

\begin{tabular}{lll}
\hline Farming experience & No. of respondents & Percentage \\
\hline Up to 10 years & 12 & 20.00 \\
11-20 years & 16 & 26.66 \\
21-30 years & 23 & 38.33 \\
Above 31 years & 10 & 16.66 \\
Total & 60 & 100.00 \\
\hline
\end{tabular}

Table-3 shows relationship between farming experiences of rice farmer's. the respondents having farming experience of up to 10 years; they had $20.00 \%$ years of farming experience had $26.66 \%, 21-30$ years of farming experience possessed $38.33 \% 30$ years of $16.66 \%$ of rice growers in the study area.

\subsection{Marital Status}

Marital status is the condition of being married, unmarried, divorced or widowed. Marriage is a legal contract between people called spouses. Widowed this category includes persons who have lost their legally married spouse through death and who have not remarried. Divorced this category includes persons who have obtained a legal divorce and have not remarried. Single this category includes persons who have never married. 
Table 4. Marital status of the rice farmers in the study area

\begin{tabular}{lll}
\hline Marital Status & No. of respondents & Percentage \\
\hline Single & 15 & 25.00 \\
Married & 40 & 66.66 \\
Divorced / Widow & 5 & 8.33 \\
Total & 60 & 100.00 \\
\hline
\end{tabular}

Table- 4 shows that rice farmer's there were $25.00 \%$ were single marital status, $66.66 \%$ were married marital status, and $8.33 \%$ were widow/divorced in the study area.

\subsection{Family Type}

Joint family set-up, the workload is shared among the members, often unequally. Extended family defines a family that extends beyond the nuclear family, consisting of grandparents, aunts, uncles, and cousins all living nearby or in the same household.

Table 5. Family type of the rice farmers in the study area

\begin{tabular}{lll}
\hline Family type & No. of respondents & Percentage \\
\hline Joint & 38 & 63.33 \\
Single & 22 & 36.66 \\
Total & 60 & 100.00 \\
\hline
\end{tabular}

Table- 5 shows that rice farmer's there were $63.33 \%$ were joint family system and $36.66 \%$ were single family type in the study area.

\subsection{Occupation}

A person's usual or principal work or business, especially as a means of earning a living; vocation: Her occupation was dentistry.

Table 6. Occupation of the rice farmers in the study area

\begin{tabular}{lll}
\hline Occupation & No. of respondents & Percentage \\
\hline Farming & 38 & 70.00 \\
Farming + Shopkeeper & 7 & 10.00 \\
Farming + Job & 15 & 20.00 \\
Total & 60 & 100.00 \\
\hline
\end{tabular}

Table-6 shows that rice farmer's there were $70.00 \%$ farmers were engaged in farming, $10.00 \%$ of the respondents were engaged in their jobs as well as in farming and $20.00 \%$ of the respondents were engaged in the business lie having shops.

\subsection{Working Time}

Working time is the period of time that an individual spends at paid occupational labor. Working time may vary from person to person often depending on location, culture, lifestyle choice, and the profitability of the individual's livelihood.
Table 7. Working time of the rice farmers in the study area

\begin{tabular}{lll}
\hline Working time & No. of respondents & Percentage \\
\hline Up to 5 hrs & 07 & 11.66 \\
$6-10$ yrs & 44 & 73.33 \\
$11-15$ hrs & 09 & 15.00 \\
Total & 60 & 100.00 \\
\hline
\end{tabular}

Table-7 shows about the number of working hours spent in fields by the respondents. 6-10 hours in their fields and they had $73.33 \%$, the respondents spent up to 5 hours in their farming activities and had $11.66 \%$. While only 09 of the respondents were spending 11-15 hours in their fields having $15.00 \%$ of the rice farmer's in the study area.

\subsection{Farmer Status}

A farmer is a person engaged in agriculture, raising living organisms for food or raw materials. A farmer might own the farmed land or might work as a laborer on land owned by others, but in advanced economies, a farmer is usually a farm owner, while employees of the farm are farm workers, farmhands, etc. A tenant farmer is one who resides on and farms land owned by a landlord. Tenant farming is an agricultural production system in which landowners contribute their land and often a measure of operating capital and management; while tenant farmers contribute their labor along with at times varying amounts of capital and management.

Table 8. Land tenure of the rice farmers in the study area

\begin{tabular}{lll}
\hline Farmer Status & No. of respondents & Percentage \\
\hline Owner & 39 & 65.00 \\
Owner Cum Tenant & 10 & 16.70 \\
Tenant & 11 & 18.30 \\
Total & 60 & 100.00 \\
\hline
\end{tabular}

Table- 8 shows that rice farmer's there were 65.00 percent were owner, 18.30 percent were owner cum tenant and 16.70 percent of the respondents were identified as tenant in taluka Pano Akil district Sukkur Sindh.

\subsection{Crop Seasons and Cropping Patterns}

There are two main crop seasons; Kharif season starts from April-May and ends in October-November while the Rabi starts from November-December and ends in April-May.

Table 9. Cropping patterns of the rice farmers in the study area

\begin{tabular}{ll}
\hline Crops & Percent area \\
\hline Kharif crops & \\
Rice & 44.6 \\
Sugarcane & 38.5 \\
Jowar & 5.6 \\
Vegetables & 6.8 \\
Others & 4.4 \\
All & 100.00 \\
Rabi Crops & \\
Wheat & 47.4 \\
Sugarcane & 38.5 \\
Barseem & 5.8 \\
Vegetables & 8.2 \\
All & 100.00 \\
\hline
\end{tabular}


Table-9 showed that the selected rice farmers during Kharif season, rice, sugarcane, Jowar and others were the major predominant crops with $44.65,38.55,5.6,6.8$ and 4.4 percent of the total cropped area, respectively. Also, wheat, sugarcane, barseem, vegetables had 47.4, 38.6, 5.8 and 8.2 percent respectively sizable share in the Rabi cropping pattern of sample rice growers.

\subsection{Rice Varieties}

Table 10. Rice varieties on the selected farms in the study area

\begin{tabular}{lll}
\hline Rice varieties & No. of respondents & Percentage \\
\hline B-2000 & 14 & 23.33 \\
Shandar & 7 & 11.66 \\
IRRI-6 & 39 & 65.00 \\
Total & 60 & 100.00 \\
\hline
\end{tabular}

Table-10 showed that the selected rice farmers were the major varietiesIRRI-6, B-2000 and Shandar covered about $65.00 \%, 23.33 \%$ and $11.66 \%$ variety planted by the selected growers on rice in taluka Pano Akil district Sukkur Sindh.

\subsection{Fixed Cost}

Fixed costs are expenses that are not dependent on the level of goods or services produced. They tend to be time related, such as tax, rents being paid per month/year and are often referred to as overhead costs.

Table 11. Per acre on fixed costs by the selected rice farmers in the study area

\begin{tabular}{ll}
\hline Particulars & Rate/Unit \\
\hline Land Tax ( per year) & 200.00 \\
Rent of Land ( per year) & 15000.00 \\
Total & 15200.00 \\
\hline
\end{tabular}

Table-11 indicated that on an average per acre rice farmers spent a sum of Rs. 15200.00 in taluka Pano Akil district Sukkur Sindh included Rs. 200.00 for land tax, Rs. 15000.00 for rent of land.

\subsection{Land Preparation}

The first and important step in wheat cultivation is land preparation that enhances the water holding capacity of the soil for long time and also it maximizes the ability of wheat plant to get required nutrients from soil. Land preparation typically involves plowing, harrowing and leveling the field to make it suitable for crop establishment.

Table 12. Per acre on land preparation used in the study area

\begin{tabular}{lllll}
\hline Particulars & Unit & Quantity & Rate/Unit & Total cost (Rs.) \\
\hline Tractor & Hours & 3.92 & 400.00 & 1600.00 \\
Labour & PDs & 2.50 & 300.00 & 750.00 \\
Total Rs. & & & & 2350.00 \\
\hline
\end{tabular}

Table-12 indicated that the per acre rice farmers average cost of land preparation came to be Rs. 2350.00. 00 in study are this included Rs. 1600.00 for tractor and Rs. 750.00.00 for labour.

\subsection{Seed Sowing}

Sowing cost is the cost incurred on seed and labor used in the application of seeds. Sowing is the process of planting seeds.

Table 13. Per acre on seed and sowing used in the study area

\begin{tabular}{lllll}
\hline Particulars & Unit & Quantity & Rate/Unit & Total cost (Rs.) \\
\hline Seed & $\mathrm{Kg}$ & 34 & 48.57 & 1700.00 \\
Labour & $\mathrm{PDs}$ & 4 & 300.00 & 1200.00 \\
Total Rs. & & & & 2900.00 \\
\hline
\end{tabular}

Table-13 indicated that on an average per acre rice farmers spent a sum of Rs.2900.00 in taluka Pano Akil district Sukkur Sindh this included Rs. 1700.00 for seed and Rs. 1200.00 for labour.

\subsection{Farm Inputs}

The resources that are used in farm production, such as chemicals equipment, feed, seed, and energy. Most farm inputs are purchased (a change from the days when animals powered most operations), making production costs susceptible to nonfarm economic conditions. Over time prices of farm inputs have increased relative to commodity prices, creating what farmers describe as a cost-price squeeze. The relationship between prices paid for inputs compared to prices received for output is quantified in the parity ratio.

Table 14. Per acre expenditure incurred on farm inputs used in the study area

\begin{tabular}{lllll}
\hline Particulars & Unit & Quantity & Rate/Unit & Total cost (Rs.) \\
\hline Urea & Bags & 2 & 2250.00 & 4500.00 \\
DAP & Bags & 1 & 5360.00 & 5360.00 \\
$\begin{array}{l}\text { Application } \\
\text { (Labour) }\end{array}$ & PDs & 2 & 300.00 & 600.00 \\
Total Rs. & & & & 9860.00 \\
\hline
\end{tabular}

Table-14 shows that each selected rice farmers of taluka Pano Akil district Sukkur Sindh on an average per acre of Rs. 9860.00, which included Rs. 4500.00, Rs. 5360.00 and Rs. 600.00 on urea, DAP and labour.

\subsection{Harvesting/Threshing}

Table 15. Per acre expenditure on harvesting/threshing in study area

\begin{tabular}{lllll}
\hline Particulars & Unit & Quantity & Rate/Unit & Total cost (Rs.) \\
\hline Harvesting & Per acre & 4 & 300.00 & 1200.00 \\
Threshing & Mounds & 3 & 1200.00 & 3600.00 \\
Empty bags & Per bag & 40 & 55.00 & 2200.00 \\
Total Rs. & & & & 7400.00 \\
\hline
\end{tabular}

Table-15 the average cost of harvesting is Rs. 1200.00 per acre, Mechanical thresher was used for threshing of the crop. Threshing charges were paid in kind and were converted to monetary unit on per acre basis. Per acre cost of harvesting/threshing was Rs. 7400.00 showing production of rice. 


\subsection{Marketing Costs}

Table 16. Per acre expenditure incurred on marketing cost in study area

\begin{tabular}{lllll}
\hline Particulars & Unit & Quantity & Rate/Unit & Total cost (Rs.) \\
\hline Loading & PDs & 5 & 300.00 & 1500.00 \\
Transportation & - & - & 3600.00 & 3600.00 \\
Unloading & PDs & 5 & 300.00 & 1500.00 \\
Total Rs. & & & & 6600.00 \\
\hline
\end{tabular}

Table-16its clear from result that each selected rice farmers in taluka Pano Akil district Sukkur Sindh area on average per acre spent a sum of Rs. 6600.00, this included Rs. 1500.00 for loading, Rs. 3600.00 for transportation and Rs. 1500.00 of unloading .

\subsection{Total Cost of Production}

TCP defined as sum of fixed cost plus variable costs make the total cost of production.

Table 17. Per acre total cost of production in the study area

\begin{tabular}{ll}
\hline Particulars & Rate (Rs.) \\
\hline Fixed cost & 15200.00 \\
Land preparation & 2350.00 \\
Seed and sowing & 2900.00 \\
Farm inputs & 9860.00 \\
Harvesting and threshing & 7400.00 \\
Marketing cost & 6600.00 \\
Total & 44310.00 \\
\hline
\end{tabular}

Table-17 the selected rice farmers on average per acre spent a total cost of production of Rs. 44310.00 , this included Rs. 15200.00 , Rs. 2350.00, Rs. 2900.00, Rs. 9860.00, 7400.00 and Rs. 6600.00 on fixed cost, Land preparation, Seed and sowing, Farm inputs, Harvesting and threshing marketing costs respectively on capital inputs.

\subsection{Gross Returns}

Gross returns depend on; 1) rice grain and 2) rice straw/palal from rice production. The returns from rice also depend on prices of these products received by the farmers.

Table 18. Per acre expenditure incurred on gross returns in the study area

\begin{tabular}{lllll}
\hline Particulars & Unit & Quantity & Rate/Unit & Total cost (Rs.) \\
\hline Rice grain & Mound & 78 & 900.00 & 70200.00 \\
Straw & Mound & 50 & 200.00 & 10000.00 \\
Total Rs. & & & & 80200.00 \\
\hline
\end{tabular}

Table-18the selected rice farmers on average per acre gross return of Rs. 80200.00 , Rs. 70200.00 on rice grain, Rs. 10000.00 on straw in taluka Pano Akil district Sukkur Sindh.

\subsection{Net Income}

Net income is gross profits remains cash operating expenses and depreciation cost of machinery and equipments costs could be obtained by subtracting the gross revenue from cash operating expenses.

Table 19. Per acre net income realized by the selected wheat in the study area

\begin{tabular}{ll}
\hline Particulars & Rate (Rs) \\
\hline Gross income (Rs) A & 80200.00 \\
Total Expenditure (Rs.) B & 44310.00 \\
Net Income (Rs.) A-B=C & 35890.00 \\
\hline
\end{tabular}

Table-19the rice farmers on an average per acre earned during study, Rs. 35890.00 on net income, Rs. 80200.00 on gross income and Rs. 44310.00 on total expenditure in taluka Pano Akil district Sukkur Sindh.

\subsection{Input-Output Ratio}

Table 20. Per acre input-output ration calculated by the selected rice farmers

\begin{tabular}{llll}
\hline $\begin{array}{l}\text { Area } \\
\text { sown }\end{array}$ & $\begin{array}{l}\text { Gross income } \\
\text { (Rs.) }\end{array}$ & $\begin{array}{l}\text { Total } \\
\text { expenditure }\end{array}$ & $\begin{array}{l}\text { Input-output } \\
\text { ratio }\end{array}$ \\
\hline Acre & (A) & $(\mathrm{B})$ & $\mathrm{A} / \mathrm{B}=\mathrm{C}$ \\
1 & 80200.00 & 44310.00 & $1: 1.80$ \\
\hline
\end{tabular}

Table-20showed that the selected rice farmers on an average per acre gross income Rs. 108400.00 and total expenditure is Rs. 68310.00 in taluka Pano Akil district Sukkur Sindh area therefore they availed input output ratio of 1: 1.80 from rice growing in the study area.

\subsection{Cost Benefit Ratio}

Table 21. Per acre cost benefit ratio calculated by the selected rice farmers

\begin{tabular}{llll}
\hline $\begin{array}{l}\text { Area } \\
\text { sown }\end{array}$ & $\begin{array}{l}\text { Net income } \\
\text { (Rs.) }\end{array}$ & $\begin{array}{l}\text { Total expenditure } \\
\text { (Rs.) }\end{array}$ & $\begin{array}{l}\text { Input-output } \\
\text { ratio }\end{array}$ \\
\hline Acre & (A) & (B) & $\mathrm{A} / \mathrm{B}=\mathrm{C}$ \\
1 & 35890.00 & 41910.00 & $1: 0.85$ \\
\hline
\end{tabular}

Table-21showed that the selected rice farmers on an net income per acre earned Rs. 38290.00and total expenditure Rs. 41910.00 in taluka Pano Akil district Sukkur Sindh area therefore, they availed input output ratio of 1:0.85from rice growing in the study area.

\section{Discussion}

In this study, identified a number of factors that believed would be influential in determining the rice production area of district Sukkur Sindh. The results are indicating that proposed model provides an acceptable fit on the data.

Krishna (2001) studied the costs and returns of paddy cultivation in Kerala through a sample of 100 farmers for the year 2000-2001. The total cost of cultivation per hectare was found to be Rs.31043.75. Of this the lion's share was attributed to human labour, which amounted for 61.46 per cent of total cost. Total returns form per hectare cultivation was Rs.27023.68. Since it was below the total cost incurred, the net income was found negative with a loss of Rs.4020.08 per hectare and the benefit -cost ratio of 0.87 , indicating unprofitable situation. However, rice and prawn cultivation 
together earned profit making B-C ratio to be 1.27 . The study concluded that there was an increased trend towards double crop of prawn due to higher profitability of the prawn farming and loss incurred in rice crop. One of the major recommendations made in the study was mechanization of rice farming operations due to higher wage rate prevailing.

Nelappa (2002) studied the costs and returns structure in cultivation of paddy in Tungabhadra command area (TBP) of North Karnataka. The profitability aspect of paddy cultivation in TBP was analyzed by computing per hectare cost and returns. The hectare cost of cultivation of paddy was Rs.26192, RS.25938 and Rs.23822 for farmers in Bellary and Raichor districts and for prize- winning farmers, respectively. The variable costs constituted the major proportion of total cost of cultivation of paddy farming, which was about 85 per cent. The expenditure on human labour was found to be major item of variable cost. The gross return per hectare of paddy cultivation was Rs.42851 (Bellary) and Rs.40735 (Raichur). It was Rs.45350 for prize-winning farmers. The net returns per rupee spent in paddy were estimated to be Rs.1.64 for farmers in Bellary, Rs.1.57 for farmers in Raichur and Rs.1.90 for prize- winning farmers.

The results of present study conducted to determine the economic implications of rice production and marketing in district taluka Pano Akil district Sukkur Sindh indicated that the farmers on an average per acre rice farmers spent a sum of Rs. 15200.00 in included Rs.200.00 for land tax, Rs. 15000.00 for rent of land and rice farmers average cost of land preparation came to be Rs.2350.00.00 and Rs.1600.00 for tractor and Rs.750.00.00 for labour. An average per acre rice farmers spent a sum of Rs.2900.00 in taluka Pano Akil district Sukkur Sindh this included Rs 1700.00 for seed and Rs.1200.00 for labour. Rice farmers of taluka Pano Akil district Sukkur Sindh on an average per acre of Rs.7460.00, which included Rs. 3500.00, Rs.3360.00 and Rs.600.00 on urea, DAP and labour.

The average cost of harvesting is Rs.1200.00 per acre; Mechanical thresher was used for threshing of the crop. Threshing charges were paid in kind and were converted to monetary unit on per acre basis. Per acre cost of harvesting/threshing was Rs.7400.00 showing production of rice. The farmers in taluka Pano Akil district Sukkur Sindh area on average per acre spent a sum of Rs.6600.00, this included Rs.1500.00 for loading, Rs3600.00 for transportation and Rs. 1500.00 of unloading . Rice farmers on average per acre spent a total cost of production of Rs. 41910.00, this included Rs.15200.00, Rs.2350.00, Rs.2900.00, Rs.7460.00, Rs.7400.00 and Rs.6600.00 on fixed cost, Land preparation, Seed and sowing, Farm inputs, Harvesting and threshing marketing costs respectively on capital inputs.

Thus the selected rice growers in district Sukkur Sindh on average per acre gross return of Rs. 80200.00, Rs. 70200.00 on rice grain, Rs. 10000.00 on straw in taluka Pano Akil district Sukkur Sindh. The rice farmers on an average per acre earned during study, Rs. 38290.00 on net income, Rs. 80200.00 on gross income and Rs. 41910.00 on total expenditure in taluka Pano Akil district Sukkur Sindh. Rice farmers on an average per acre gross income Rs. 108400.00 and total expenditure is Rs. 68310.00 in taluka Pano Akil district Sukkur Sindh area therefore they availed input output ratio of 1: 1.58 from rice growing in the study area. The selected rice farmers on a net income per acre earned Rs. 38290.00and total expenditure Rs. 41910.00 in taluka Pano Akil district Sukkur Sindh area therefore, they availed input output ratio of 1:0.91 from rice growing in the study area.

\section{Conclusions}

The purpose of this study was to investigate analysis of rice profitability and marketing in taluka Pano Akil district Sukkur Sindh. The study was based on primary data, which was collected from rice farming in taluka Pano Akil district Sukkur Sindh. A random selection of rice farming in taluka Pano Akil district Sukkur Sindh was carried out to insure the generalization of research finding. From the sample of 60 rice growers, this equally distributed from different areas of in taluka Pano Akil district Sukkur Sindh. Analysis was done by using statistical technique like means, comparison of means and frequency distribution etc. results shows that on an average per acre spent a total cost of production of rice farmers Rs.44310.00, this included Rs.15200.00, Rs.2350.00, Rs.2900.00, Rs.9860.00, Rs.7400.00 and Rs.6600.00 on fixed cost, Land preparation, Seed and sowing, Farm inputs, Harvesting and threshing marketing costs respectively on capital inputs. Rice farmers on an average per acre gross income Rs.108400.00 and total expenditure is Rs.68310.00 in taluka Pano Akil district Sukkur Sindh area therefore they availed input output ratio of 1: 1.58 from rice growing in the study area. The selected rice farmers on a net income per acre earned Rs. 38290.00and total expenditure Rs.41910.00 in taluka Pano Akil district Sukkur Sindh area therefore, they availed input output ratio of 1:0.91from rice growing in the study area.

The production rate per acre is not sufficient even with the presence of general assistance. Following suggestions are put forwarded to improve the peasant situation.

- Advising proper combination of inputs to the farmer and giving subsidy on the inputs will result in enhanced farm production.

- Credit facilities must be provided to farmers.

- The new technology must be provides to farmers

- Government should provide subsidies on fertilizer, pesticides and other micro nutrients for wheat.

- There is need of proper guide to farmers about rice arming so Government should provide and activate researchers and extension department for proper guideline of farmers.

\section{References}

[1] Black, Richard 2010.Rice yields falling under global warming BBC News Science \& Environment. Retrieved August 9, 2010. 
[2] Basanta, R.D., Peter, L. N. and Gilbert, V.N., 2004, measuring the economic inefficiency of Nepalese rice farms using data envelopment analysis. The Australian Journal of Agricultural and Resource Economics , 48 (2): 347-369.

[3] Bayo, E. F 2007. Efficiency of Factors Determining Rainfed Rice Production in Ganye Local Government Area, Adamawa State. Journal of Sustainable Development in Agriculture \& Environment Vol. 3:20-30, Sept. 2007.

[4] Chantal, P., Nielsen, 2002. Vietnam in the International Rice Market. A Review and Evaluation of Domestic and Foreign Rice Policies, Rapport 132.

[5] David Boansi (2014). Yield response of Rice in Nigeria: Acointegration analysis, Published online January 20.2014 www.sciencepublishinggroup.com/j/ajaf American Journal of Agriculture and Forestry Vol. 2. No. 2. 2014. pp15-24.

[6] Duc Hai, L.T., 2008. The Organization of the Liberalized Rice Market in Vietnam

[7] Doumach, W., C. Kodikara, and H. Maas,2004. Analysis of rice chain; towards sustainable (P) Rice, PP. 4-5, Report on an international workshop. Polonnaruwa, Sirlanka.11-3 March, 2004.

[8] FAO, 2005.Addressing Marketing and processing constraints that inhibit Agri-food Experts: a guide for policy analysts and planners. FAO agricultural service Bulletin 160. Rome, Italy.

[9] FAO2007. "Agriculture Statistics $>$ Grains $>$ Rice production (2007) by country". Retrieved 2010-05-06

[10] FAO2003. "Sustainable rice production for food security". Food and Agriculture Organization of the United Nations. 2003.

[11] FAO (FAOSTAT) 2012. "Food Balance Sheets > Commodity Balances > Crops Primary Equivalent". Retrieved August 17, 2012.

[12] FAO, 1994. African experience in the improvement of postharvest techniques. Synthesis Based on the Workshop held in Accra, Ghana, 4-8 July 1994 Agricultural Support Systems Div. Food and Agriculture Organization of the United Nations, Rome Italy.

[13] Gauraha, A.K., K.N.S.Banafar, P.K.Verma, V.K. Choudhary, and B.C. Jain, 2002. Marketing Strategies of Rice in Chhattisgarh-A Case Study, 2002. Indian Journal of agricultural marketing. Vol. 45(3).

[14] GOP, 2013. Agriculture: Economic Survey of Pakistan, 201213, Ministry of Food and Agriculture, Government of Pakistan, Islamabad.

[15] GOP, 2012. Agriculture: Economic Survey of Pakistan, 2012, Ministry of Food and Agriculture, Government of Pakistan, Islamabad.

[16] Gauraha, A.K., K.N.S.Banafar, P.K.Verma, V.K. Choudhary, and B.C. Jain, 2002. Marketing Strategies of Rice in Chhattisgarh 2002. Indian Journal of agricultural Vol. 45(3).

[17] Getachew Afework, 2000. Rice adaptation in Metema Woreda North Gondar one of the Amhara Regional State. Bureau of Agriculture, Bahir Dar. (Unpublished).

[18] Harahap H,, 2004. Rice chain analysis in North Sumatra, Indonesia. Institute.(eds.). Rice improvement in Eastern, Central and Southern Africa. Proceedings of the International Rice Workshop at Lusaka, Zambia, April 9-19, 1984.
[19] Habib, M. I., A. M. Manganhar and M.U. Shar S. 2005. An Analysis of Technical Efficiency of Rice Farmers in the Mixed Farming System of Punjab, Pakistan. MSc Thesis. University of Faisalabad, Pakistan.

[20] Harahep H,, 2004. Rice chain analysis in North Sumatra, Indonesia. Institute.(eds.). Rice improvement in Eastern, Central and Southern Africa. Proceedings of the International Rice Workshop at Lusaka, Zambia, April 9-19, 1984.

[21] Humayun 2012. "Rice". In Sirajul Islam and Ahmed A. Jamal. Banglapedia: National Encyclopedia of Bangladesh (Second ed.). Asiatic Society of Bangladesh.

[22] Iddo K., Ayal K. and Zveleman, 2006. Farm output, non-farm income and commercialization in rural Georgia, The electronic Journal of Agricultural and development Economics, Food and Agriculture Organization of the United States.Vol.3 (2): pages 276-286.

[23] Ingram. (2009). Performance and potential of market value chain rice production in Bangladesh. Paper presented at the 5th International Rice Symposium, Changsha, China.

[24] Jimjel Zalkuwi, Rakesh Singh, M adhusudan Bhattaria, O. P Singh, B.Dayakar (2015). Production cost and return; Comprative analysis of Sorghum in India and Nigeria, Published online March 24. 2015 www.sciencepublishinggroup.com/j/eco Economics Vol. 4. No. 2. 2015. pp18-21.

[25] Krishna, 2001, Sustainability and economic efficiency of rice farming in the agro- ecological problem area zone of Kerala. M.Sc. Thesis , Department of Agricultural Economics, University of Agricultural Sciences, Bangalore

[26] Khush, 2005. Marketable Surplus of Rice and Wheat and Benefits of Storage to the Farmers in India. Indian Agricultural marketing journal. Vol. 46

[27] Khushk, A. M., and L. E. D, Smith. 2011. Economics Analysis of the Marketing of Rice in Sindh Province of Pakistan. The Pakistan Economic Development Review, 35 (3): Pp. 241-255

[28] Moses, J., and Adebayo, E. F 2007. Efficiency of Factors Determining Rainfed Rice Production in Ganye Local Government Area, Adamawa State. Journal of Sustainable Development in Agriculture \& Environment Vol. 3:20-30, Sept. 2007.

[29] Md. Nehal Hasnain, Md. Elias Hossain, Md . Khairul Islam (2015). Technical efficiency of boro Rice production in Meherpur District of Bangladesh: A Stochastic fornitier approach, Published online March 6.2015 www.sciencepublishinggroup.com/j/ajaf American Journal of Agriculture and ForestryVol.3.No.2.2015.pp31-37.

[30] Md. Abu zaman Sarker, Md, Ashraful Alam, Akbar Hossain, Md, Abdul Mannaf, (2014). Agro-economic performance of crop diversification in Rice based cropping systems of northwest Bangladesh. Published online August 302014 www.sciencepublishinggroup.com/j/aff Agriculture, Forestry and fisheries Vol.3.No.4.2014.pp264-270.

[31] Neelappa, S., 2002, Technical and allocative efficincy of paddy production in TBP area - An Economic analysis. M.Sc. Thesis, Department of Agricultural Economics, UAS, Dharwa

[32] Obasi, I.O., and E. Njpkuoma Chukwuma, 2008. Performance of rice market in Ebonyi State. Journal of economic theory. 2(1):22-23. 
[33] Reddy, A.R. and Sen, C., 2004, Technical inefficiency in rice production and its relationship with farm-specific socioeconomic characteristics. Indian Journal of Agricultural Economics , 59 (2): 259-267.

[34] Raisunddin, A., 2004, Rice economy of Bangladesh, progress and prospects. Economic and Political Weekly, 39 (36): 40434051.

[35] Singh 2000. Rice cultivation and market analysis in Amhara National Regional State: the case of Fogera woreda, South Gondar zone. An M.Sc Thesis Presented to the School of Graduate Studies of Haramaya University.

[36] Singh, 2002. Marketed surplus of paddy- A regression analysis National Level Quarterly Journal of Agricultural marketing. Vol. 45 (2).

[37] Singh, J.P., 2001. Strategy for effective agricultural Marketing extension to meet the Challenges in 21 st century. Manage Extension Research Review July - December, 2001.

[38] Sharma, S.D. 2004. The household responsibility system reform and the adoption of hybrid rice in china. Journal of Development Economics, 36(2), 353-372.
[39] Shahidullah, Aldas, \& Hossain, Mahabub. 2009. Can hybrid rice technology help productivity growth in asian tropics. Farmers' experiences. Economic and Political Weekly, 38(25), 2492-2501.

[40] Singh, 2002. Marketed surplus of paddy- A regression analysis National Level Quarterly Journal of Agricultural marketing. Vol. 45 (2).

[41] Shahi, B.B., 1995. Potential rice varieties for East Africa. Proceedings of the International Rice Workshop on Rice improvement in Eastern, Central and Southern Africa. Lusaka, Zambia, 9-19 April, 1995.

[42] Taddese Yeneneh, 2005. Rice crop production and Extension package (Amharic version), Addis Abeba ,Ethiopia.

[43] Visva, 2001. Analysis of rice chain; towards sustainable (P) Rice, PP. 4-5, Report on an international workshop. West Bengal,.11-3 March, 2001.

[44] Wolelaw Sendeku, 2005. Factors determining supply of rice: A study in Fogera district of Ethiopia. An M.Sc Thesis Presented to the School of Graduate Studies of Hararnay University. 